\title{
Prospective monitoring of drug use: drug-induced liver injury in a primary healthcare center
}

\author{
Nília Maria de Brito Lima PRAD0 ${ }^{1}$, Gladistone Correia MESSIAS'르, Genário Oliveira SANTOS JUNIOR², \\ Vinícius Santos NUNES ${ }^{2}$, Maria Isabel SCHINONNI ${ }^{3}$ and Raymundo PARANÁ ${ }^{4}$
}

Received 8/7/2019

Accepted 27/9/2019

\begin{abstract}
Background - Drug-induced liver injury is still misunderstood in Brazil due to diagnostic difficulties or lack of reporting incidents. Objective - To assess the frequency of adverse events related to the use of medicines in a primary healthcare unit, in a city locate southwestern of the state of Bahia, Brazil. Methods - Prospective study conducted at the Primary Center for Specialized Health (CEMEA), February at August of 2013 in Vitoria da Conquista, Bahia, Brazil. Interviews were conducted with patients over 18 years old, and their clinical and laboratorial data were collected. The CIOMS scale was used to validate the cases. Results - A total of 149 patients, mainly Afro-Brazilian women, received follow-up. Among these patients, three cases of hepatotoxicity were identified, and the medicines associated to drug-induced liver injuries were: nimesulide, budesonide and valacyclovir. Conclusion - Drug-induced liver injury is rare in primary healthcare units. It also allowed estimating the incidence of hepatotoxicity induced by allopathic medicines which are standardized by public healthcare authorities.
\end{abstract}

HEADINGS - Chemical and drug induced liver injury. Drug-related side effects and adverse reactions. Pharmacovigilance.

\section{INTRODUCTION}

Pharmacotherapy plays an important role in preserving and reestablishing people's good health conditions, thus contributing to improve the quality of life and life expectancy of the population. The ongoing progress of Health Sciences allows the introduction of new pharmaceutical products that either prevent or treat diseases that were thought untreatable. However, the misuse of medicines is one of the main causes of health issues as well as social and economic losses.

Therefore, it is essential that pharmaceutical products are used in a rational manner, in order to ensure the desired therapeutic effects. According to the World Health Organization (WHO), the rational use of medicines requires that "patients receive medications appropriate to their clinical needs, in doses that meet their own individual requirements, for an adequate period of time, and at the lowest cost to them and their community"(1).

One of the main causes of liver disease is drug-induced liver injury (DILI), which is directly related with toxicity by drug therapy to which certain susceptible patients are subjected to ${ }^{(2)}$. The World Health Organization defines adverse reaction as "a response to a drug which is noxious and unintended, and which occurs at doses normally used in man for the prophylaxis, diagnosis, or therapy of disease, or for the modification of physiological function. ${ }^{(3) \text { " }}$

In addition, some factors make people susceptible to or predisposed to develop liver injury, such as age, gender, nutritional status, use of allopathic medicine, herbal or dietary supplements
(HDS), polypharmacy, drug or alcohol abuse. Besides elderly people, women, and children are the most vulnerable groups ${ }^{(4-8)}$.

DILI is observed both in hospitals and outpatient units. Prospective data on adverse events concerning patients in outpatient clinics are rather scarce. This scarcity is the result of several factors, such as lack of patient/physician communication, self-administration of medications by patients, and inadequate documentation.

In Brazil, data on drug-induced hepatotoxicity in outpatient clinics are extremely limited. Literature reviews did not show results of surveys in healthcare units, neither in primary nor secondary care. In addition, the knowledge of specific risk factors that favor adverse reactions to medications allows the implementation of preventive actions and actions to raise awareness about the system of medicine use.

\section{METHODS}

A cohort prospective study, was conducted at the Primary Center for Specialized Health (CEMEA) in Vitoria da Conquista, located in the southwestern region of the state of Bahia, Brazil. CEMEA is a public healthcare center which offers specialized medical services that serve both this city and neighboring towns. Patients were enrolled during the study period from February to August 2013. The project aimed to put together healthcare professionals and expert physicians, thus building a collaborative network that allowed the assessment of the incidence of drug-induced liverrelated adverse events. 
The inclusion criteria of the study were: patients over 18 years old, who sought gastro-hepatology services and received follow up in this outpatient unit, and who were taking medicines prescribed by local physicians.

The exclusion criteria were: patients who consumed alcohol in amounts $>30 \mathrm{~g} /$ day, presenting with non-hepatic USG ABD, non-reactive viral serologies (viral hepatitis A, B and C, herpes and EBV), immunoglobulins, iron kinetics, ceruloplasmin and alpha 1 antitrypsin were included, if normal ${ }^{(9)}$.

The interviews were held just before the physicians visit, with a pharmacist. A questionnaire with a list of questions specifically conceived for the study was applied. The medical records of the interviewed patients were filled with the confirming and completing of the data entered on the forms. The following information was required: clinical characteristics, time for the symptoms to begin, signs such as fever, rash, lymphadenopathy, splenomegaly, anorexia, nausea, abdominal discomfort, jaundice, dark urine, white stools, and arthritis, use of allopathic or/and phytotherapic medicines, herbal and dietary supplements, and risk factors such as existing liver disease, alcohol use, nutritional status and data on the occurrence of autoimmune or viral hepatitis.

After the first interview (D1), all the patients who had prescription of medicines were invited to return in thirty days (D30), in order to evaluate liver function through signs and/or symptoms, and biochemical parameters such as alanine transaminase, alkaline phosphatase, bilirubin, alanine aminotransferase, gamma glutamyl transpeptidase and hemogram. In the case of suspicion of DILI, the patient was evaluated by a physician and returned to the health service in sixty days (D60) and ninety days (D90), or by the time the signs and symptoms normalize.

The biochemical criteria that characterized DILI were: alanine transaminase $(\mathrm{ALT}) \geq 5 \mathrm{x}$ higher than the normal limit $(\mathrm{xULN})$; alkaline phosphatase (ALP) $\geq 2 x$ ULN or ALT $\geq 3 x$ ULN + bilirubin (TB) $\geq 2 \times$ ULN. The type of liver injury was classified according to $R$ values (ALT/ULN)/(ALP/ULN), which were calculated from the blood tests taken after DILI suspicion.

The patients who had suspected drug-induced liver injury were required to do the serology (HAV, HBV, HCV, CMV, EBV) and autoantibodies (FAN, Anti-LKM, AML) exams, abdominal ultrasound, in order to exclude other liver diseases.

The Council for International Organizations of Medical Sciences (CIOMS) ${ }^{(10)}$ scale was applied to all cases that were diagnosed as DILI. The experts' team who confirmed the diagnoses was composed by two physicians and one pharmacist.

Statistical analyses were performed with the use of the SPSS (Statistical Package for the Social Sciences) software.

The Ethics Committee of Professor Edgard Santos University Hospital approved the study. All subjects gave informed written consent to participate in the study.

\section{RESULTS}

The study assessed data of 149 patients consulted by the gastro-hepatologist at the outpatient clinic (D1). All patients returned on Day 30 . The average age was $49(+/-13.8), 121$ of the interviewed patients $(81 \%)$ were Afro-Brazilians, and $93(62 \%)$ patients were females.

Of all patients, $78(52 \%)$ were using more than three medicines concurrently, but only $3(2 \%)$ presented liver injury after taking the medication. None patient included in this study, related HDS use.
The patients with DILI were female and the average age was 38 years. The culprit drugs were: nimesulide, budesonide and valacyclovir. The type of liver injury was hepatocellular in all cases, with the same clinical presentation. Apart from elevations in transaminases, the patients did not present other signs or symptoms of liver injury (TABLE 1). All the patients were making use of concomitant drugs. The CIOMS scale showed "probable" reaction for two patients and "possible" reaction for one. All three cases were resolved and the patients did not need hospitalization (TABLE 2). About the treatment for DILI, in all this cases, the culprit drug was discontinued, and drug therapy was not necessary to resolve the problem.

\section{DISCUSSION}

Rational use of medicines seems to be a huge challenge in outpatient units in Brazil, not only because there is an overprescription of drugs, but also due to interactions between drugs or drug misuse.

The most important adverse event related to the inadequate use of medicines is DILI. Andrade et al. (2005) emphasized the need for studies like the present one - on prospective data from outpatient medical centers - thus developing a "pharmacoepidemiology" approach to investigate such occurrences ${ }^{(11)}$.

DILI includes a complex pathophysiology, multifactorial causes, and diagnostic challenges ${ }^{(6,11)}$. Moreover, DILI diagnosis requires an assessment of the individual's overall health, risk factors, as well as drugs under use which interact with each other, alcohol exposure, and previous liver diseases ${ }^{(10)}$.

TABLE 1. Biochemical parameters of the patients who developed DILI prior, during, and after administration of suspicious drug in CEMEA, in Vitoria da Conquista-Bahia-Brazil.

\begin{tabular}{llll}
\hline Laboratory tests & D1 & D30 & D90 \\
\hline AST (UI/L) & 22 & 110 & 32 \\
Case 1 & 26 & 156 & 38 \\
Case 2 & 21 & 126 & 32 \\
Case 3 & & & \\
ALT (UI/L) & 32 & 182 & 36 \\
Case 1 & 31 & 176 & 39 \\
Case 2 & 32 & 182 & 32 \\
Case 3 & & & \\
GGT (UI/L) & 30 & 210 & 73 \\
Case 1 & 31 & 217 & 61 \\
Case 2 & 32 & 224 & 52 \\
Case 3 & & & \\
TB (mg/dL) & 0.3 & 0.6 & 0.4 \\
Case 1 & 0.4 & 0.5 & 0.3 \\
Case 2 & 0.4 & & \\
Case 3 & 3LI & & \\
\hline
\end{tabular}

DILI: drug-induced liver injury. ALT: alanine aminotransferase, ULN <40; GGT: gamma glutamyl transpeptidase, ULN <40; AST: aspartate aminotransferase: ULN <36; TB: total bilirubin, ULN $<1.20$. ULN: upper limit of normal. 
TABLE 2. Characteristics and clinical presentation of the patients who developed DILI after administration of suspicious drug in CEMEA, in Vitoria da Conquista-Bahia-Brazil.

\begin{tabular}{|c|c|c|c|c|c|c|c|c|}
\hline Case & $\begin{array}{c}\text { Age } \\
\text { (female) }\end{array}$ & $\begin{array}{l}\text { Culprit } \\
\text { drug }\end{array}$ & $\begin{array}{c}\text { Indication } \\
\text { use }\end{array}$ & $\begin{array}{c}\text { Clinical } \\
\text { presentation }\end{array}$ & $\begin{array}{c}\text { Type of liver injury } \\
\text { (Hepatocellular) }\end{array}$ & Concomitant drugs & CIOMS & Outcome \\
\hline 01 & 35 & Nimesulide & Headache & $\begin{array}{l}\text { Transaminases } \\
\text { elevation }\end{array}$ & ALT:235, ALP:52 & $\begin{array}{l}\text { Levothyroxine, } \\
\text { Nortriptyline, Torsilax }\end{array}$ & Probable & Resolved \\
\hline 02 & 42 & Budesonide & Sinusitis & $\begin{array}{l}\text { Transaminases } \\
\text { elevation }\end{array}$ & ALT:230, ALP:46 & $\begin{array}{l}\text { Hydrochlorothiazide, } \\
\text { Methyldopa, Prednisone }\end{array}$ & Probable & Resolved \\
\hline 03 & 38 & Valacyclovir & $\begin{array}{l}\text { Herpes } \\
\text { simplex }\end{array}$ & $\begin{array}{c}\text { Transaminases } \\
\text { elevation }\end{array}$ & ALT:228, ALP: 46 & $\begin{array}{l}\text { Hydrochlorothiazide, } \\
\text { Methyldopa }\end{array}$ & Possible & Resolved \\
\hline
\end{tabular}

DILI: drug-induced liver injury. ALT: alanine aminotransferase, ULN <40; ALP: alkaline phosphatase, ULN <290; ULN: upper limit of normal; CIOMS: Council for International Organization of Medical Sciences.

The present study assessed 149 patients who were all using at least one drug. Many of these patients were taking two or more medicines, and some of them have been using seven different medicines for a long time, hence they were more susceptible to develop adverse events, notably, drug-induced hepatotoxicity ${ }^{(7,8)}$. However, even among patients using multiple concomitant medicines, there was no screening protocol resulting in DILI.

The current study found three cases of DILI, which is a low frequency when compared to other prospective studies in the literature in which the number of patients with DILI was between 31 and 300 , and the observation time of these studies was from 24 to 48 months respectively ${ }^{(12,13)}$. Such a low frequency could be related to the limited time available to observe the adverse effects on the population. None of the patients with DILI had any diagnosis of previous hepatic disease. Some studies report that $2 \%$ of suspected DILI cases occur in patients with chronic liver disease ${ }^{(13)}$.

The culprit drugs found in the present study were already mentioned in others studies. Among them, AINES is the most common responsible agent of DILI in Latin America, with an incidence of $32 \%(62 / 171)^{(14)}$. In addition, nimesulide was the anti-inflammatory which most caused DILI in an Italian Center, responsible for $82 \%$ of cases in a period of ten years $(14 / 17)^{(15)}$. Budesonide is a corticoid, and corticosteroid therapy can cause hepatic steatosis and hepatic enlargement, but these conditions are often not clinically apparent, especially in adults. These effects can occur quite rapidly and are equally rapidly reversed with discontinuation of the medicine. Cases of DILI caused by the use of budesonide are uncommon but, as for the present study, liver diseases such as viral hepatitis and autoimmune diseases were excluded. Regarding the use of concomitant drugs, the patient was making use of them for a long time by the moment of the assessment, but the transaminases elevation was observed only after the use of budesonide, thus the use the concomitants drugs improve the risk of DILI, especially prednisone and betamethasone, both corticosteroid drugs ${ }^{(16)}$.

The antiviral valacyclovir was also already reported in literature as a causing agent of DILI. The patient underwent therapy for seven days and developed DILI, with transaminases elevation similar to the present study(17).

In most cases of DILI, previous exposure to at least one medicine as well as the combination of hepatotoxic drugs considerably increases the risk of DILI. As for the present study, all the patients who developed liver injury were taking concomitants drugs ${ }^{(18)}$.

The study assessed the general characteristics of each individual, such as age, gender, and obesity as risk factors for the development of liver injury. The population was composed mainly by Afro-Brazilian women, with an average age of 49 years old. Moreover, $22 \%$ of the patients were overweight. All the patients who developed DILI were female with an average age of 38 years old. In a similar study conducted in India, the average age was 38 years old and $53 \%$ of the patients were female ${ }^{(19)}$.

By the moment of the assessment, only three patients had suspected DILI, of hepatocellular type, with this result being compatible with other studies ${ }^{(15,16,18)}$.

The CIOMS method resulted in "probable" for two cases and "possible" for one. Its application becomes relevant as it considers the main criteria for imputation of causality in hepatic damage and has greater specificity, as already described in the literature.

Other authors have mentioned antibiotics as the most common type of medicine resulting in drug-induced hepatotoxicity. Also, the use of NSAIDs (nonsteroidal anti-inflammatory drugs) is quite common in the general population, and their association with drug-induced liver injury is expressive, especially diclofenac and nimesulide ${ }^{(10)}$.

As the study assessed the medicines with greater implication in DILI cases, we observed that all of them are included on Lists of Essential Medicines all over the world. The majority of patients assessed in this study were taking at least one medicine that has been implicated in DILI cases. Therefore, it is important to properly monitor these medicines for possible adverse events.

\section{CONCLUSION}

The present prospective study allowed reporting new cases of DILI in $3(2 \%)$ outpatients. It also allowed estimating the incidence of hepatotoxicity induced by allopathic medicines which are standardized by public healthcare authorities.

\section{Authors' contribution}

Prado NMBL and Messias GC: designed the study, collected, analysed data and wrote manuscript. Santos Junior GO: wrote manuscript and revised the manuscript. Nunes VS, Schinonni MI: revised the manuscript. Paraná R: designed the study and revised the manuscript.

\section{Orcid}

Nília Maria de Brito Lima Prado. Orcid: 0000-0001-8243-5662.

Gladistone Correia Messias. Orcid: 0000-0002-3192-9432.

Genário Oliveira Santos Junior. Orcid: 0000-0001-7766-2238.

Vinícius Santos Nunes. Orcid: 0000-0002-0988-9526.

Maria Isabel Schinonni. Orcid: 0000-0001-9037-8127.

Raymundo Paraná. Orcid: 0000-0002-4019-4597. 
Prado NMBL, Messias GC, Santos Junior GO, Nunes VS, Schinonni MI, Paraná R. Monitoramento prospectivo do uso de medicamentos: lesão hepática induzida por medicamentos em um centro municipal de saúde. Arq Gastroenterol. 2019;56(4):390-3.

RESUMO - Contexto - As lesões hepáticas induzidas por drogas (DILI), ainda são mal compreendidas no Brasil devido a dificuldades diagnósticas ou à falta de relatos. Objetivo - Avaliar a frequência de eventos adversos relacionados ao uso de medicamentos em uma unidade básica de saúde, em uma cidade do sudoeste baiano. Métodos - Estudo prospectivo realizado no período de fevereiro a agosto de 2013 em Vitória da Conquista, Bahia, Brasil. Entrevistas foram realizadas com pacientes maiores de 18 anos; os dados clínicos e laboratoriais foram coletados. A escala do CIOMS foi usada para avaliar causalidade dos casos. Resultados - Um total de 149 pacientes, principalmente mulheres afro-brasileiras, receberam acompanhamento. Entre esses pacientes, três casos de hepatotoxicidade foram identificados e os medicamentos associados à DILI foram: nimesulida, budesonida e valaciclovir. Conclusão - DILI é raro em unidades básicas de saúde. Os três casos foram todos reversíveis, sem necessidade de internação hospitalar. Políticas de saúde que fomentam a prática da farmacovigilância são extremamente importantes para a prevenção e deteç̧ão de DILI.

DESCRITORES - Doença hepática induzida por substâncias e drogas. Efeitos colaterais e reações adversas relacionados a medicamentos. Farmacovigilância.

\section{REFERENCES}

1. WHO. The Pursuit of Responsible Use of Medicines: Sharing and Learning from Country Experiences78. Publication date: October 2012.

2. Lee WM, Senior JR. Recognizing drug-induced liver injury: current problems, possible solutions. Toxicol Pathol. 2005;33:155-64.

3. WHO. The Importance of Pharmacovigilance - Safety Monitoring of Medicinal Products. 2002.

4. Lee WM. Drug Induced Hepatotoxicity. The New England Journal of Medicine. 2003;5:474-85.

5. Sedky K, Nazir R, Joshi A, Kaur G, Lippmann S. Which psychotropic medications induce hepatotoxicity? Gastroenterology. 2012;34:53-61.

6. Farmer AD, Brind A. Drug-Induced liver injury. Gastroenterology, 2011.

7. Bjornsson E, Davidsdottir L. The long-term follow-up after idiosyncratic drug-induced liver injury with jaundice. Journal oh Hepatology. 2009;50:511-7.

8. Gandhi TK, Weingart SN, Borus J, Seger AC, Peterson J, Burdick E, et al. Adverse Drug Events in Ambulatory Care. N Engl J Med. 2003;348:1556-64.

9. Kaplan MM, Pratts DS. Laboratory tests in diseases of the liver. $8^{\mathrm{a}}$ ed. Uol 1. Philadelphia lippincott, Raven, 1999.

10. García-Cortés M, Stephens, C, Lucena MI, Fernández-Castañer A, Andrade RJ. Causality assessment methods in drug induced liver injury: Strengths and weaknesses. J. Hepatol. 2011;55:683-91.

11. Andrade RJ, Lucena MI, Fernández MC, Pelaez G, Pachkoria K, García-Ruiz E, et al. Drug-Induced Liver Injury: An Analysis of 461 Incidences Submitted to the Spanish Registry Over a 10-Year Period. Gastroenterology. 2005:512-21.
12. Wai CT, Tan BH, Chan CL, Sutedja DS, Lee YM, Khor C, Lim SG. Drug-induced liver injury at an Asian center: a prospective study. Liver International. 2007;27:465-74

13. Chalasani N, Fontana RJ, Bonkovsky HL, Watkins PB, Davern T, Serrano J, et al. Causes, Clinical Features, and Outcomes From a Prospective Study of Drug-Induced Liver Injury in the United States. Gastroenterology. 2008;135:1924-34.

14. Hernández N, Bessone F, Sánchez A, Di Pace M, Brahm J, Zapata R, et al. Profile of idiosyncratic drug induced liver injury in Latin America: an analysis of published reports. Ann Hepatol. 2014;13:231-9.

15. Licata A, Calvaruso V, Cappello M, Craxì A, Almasio PL. Clinical course and outcomes of drug-induced liver injury: nimesulide as the first implicated medication. Dig Liver Dis. 2010;42:143-8.

16. Sagir A, Wettstein M, Oette M, Erhardt A, Häussinger D. Budesonide-induced acute hepatitis in an HIV-positive patient with ritonavir as a co-medication. AIDS. 2002;16:1191-2.

17. Renkes $\mathrm{P}$, Trechot $\mathrm{P}$, Blain H. Valaciclovir-induced hepatitis. Acta Clin Belg. 1999;54:17-8.

18. Chen M, Suzuki A, Borlak J, Andrade RJ, Lucena MI. Drug-induced liver injury: Interactions between drug properties and host factors. J Hepatol. 2015;63: 503-14.

19. Devarbhavi H, Patil M, Reddy VV, Singh R, Joseph T, Ganga D. Drug-induced acute liver failure in children and adults: Results of a single-centre study of 128 patients. Liver Int. 2018;38:1322-9. 